\title{
RELASI ORANGTUA-ANAK MENURUT PERSPEKTIF ISLAM DAN KAITANNYA DENGAN KESEJAHTERAAN PSIKOLOGIS (STUDI PENGEMBANGAN DAN VALIDASI INSTRUMEN)
}

\author{
Ayu Lestari \\ sri.wahyuni@uin-suska.ac.id \\ Fakultas Psikologi \\ UIN Sultan Syarif Kasim Riau
}

\author{
Sri Wahyuni
}

Fakultas Psikologi

UIN Sultan Syarif Kasim Riau

\begin{abstract}
Two studies are conducted within this research, specifically composing the scale of parent-child relations based on Islamic perceptions and observing the correlation between parent-child relationship variables with psychological well-being. The scale of psychological well-being uses Ryff's theory (1989) while the scale of parent-children relation is carried out through four stages, including the conceptualization of the scale and arrangement of items based on the Koran, Hadith, expert opinion, and the results of previous studies; test construct validity and content; scale improvement and validity \& reliability tests using Rasch Model analysis with WINSTEPS; and concurrent validity tests. The total number of respondents in the study was 490 respondents. The results showed that there are 36 valid and reliable items. This scale has good quality and performance which can be used to measure parent-child relations, especially in Muslim populations. Furthermore, the parent-child relationship variable based on an Islamic perspective also proved to have a very significant positive correlation with psychological well-being in children.
\end{abstract}

Keyword: parent-child relationship based on Islamic perspective, psychological wellbeing.

\begin{abstract}
Abstrak
Pada penelitian ini akan dilakukan dua studi, yaitu penyusunan skala relasi orangtua-anak berdasarkan perspektif Islam dan uji korelasi antara variabel relasi orangtua-anak dengan kesejahteraan psikologis. Skala kesejahteraan psikologis menggunakan teori Ryff (1989). Penyusunan skala relasiorangtua dilakukan melalui empat tahap, yaitu konseptualisasi skala dan penyusunan item berdasarkan Al-Quran, Hadits, pendapat ahli, dan hasil penelitian sebelumnya; uji validitas konstruk dan isi; perbaikan skala serta uji validitas dan reliabilitas menggunakan analisis Rasch Model dengan WINSTEPS; dan uji validitas konkuren. Jumlah responden penelitian secara keseluruhan adalah 490 responden. Hasil analisis akhir menemukan bahwa jumlah item yang valid dan reliabel adalah 36 item. Skala ini
\end{abstract}


memiliki kualitas dan performansi yang baik yang dapat digunakan untuk mengukur relasi orangtua-anak khususnya pada populasi Muslim. Selanjutnya, variabel relasi orangtua-anak berdasarkan perspektif Islam juga terbukti berkorelasi positif yang sangat signifikan dengan kesejahteraan psikologis pada anak.

Kata kunci: relasi orang tua-anak berdasarkan perspektif Islam, kesejahteraan psikologis.

\section{PENDAHULUAN}

Anak adalah anugerah yang diberikan Allah SWT kepada orangtua. Setiap orangtua tentunya memiliki impian bahwa anaknya mencapai kebahagiaan dan sejahtera di dalam kehidupannya. Anak yang memiliki kesejahteraan psikologis terlihat dari kemampuannya dalam menerima segala kelebihan dan kekurangannya, mampu menjalin relasi interpersonal yang baik dengan orang lain, mandiri, menguasai dan mampu beradaptasi dengan lingkungan, memiliki tujuan hidup, dan mampu mengembangkan potensi yang dimiliki (Ryff, 1989).

Kebahagiaan dan kesejahteraan anak sangat tergantung kepada bagaimana relasinya dengan orangtua. Penelitian yang dilakukan oleh Armsden dan Greenberg (1987) menemukan bahwa relasi yang kuat antara anak dengan orangtua memiliki sumbangsih atas terbentuknya kesejahteraan psikologis pada anak. Hal ini disebabkan karena orangtua memiliki peran yang penting dalam kehidupan anak. Orangtua merupakan sumber pengasuhan, perlindungan, dan teladan bagi anak-anaknya. Relasi orangtua-anak merupakan sumber dan dasar perkembangan psikologis, kebahagiaan, serta kesejahteraan bagi sang anak hingga dewasa.

Secara lebih luas, Noor, Gandhi, Ishak dan Wok (2012) mengungkapkan bahwa kesejahteraan keluarga (anak dan orangtua) terbentuk oleh beberapa komponen, yaitu relasi anggota keluarga yang baik, kondisi ekonomi, kesehatan dan keselamatan anggota keluarga, hubungan dengan masyarakat, dan agama atau tingkat spiritualitas. Relasi orangtuaanak yang baik tersebut dapat dilihat dari bagaimana orangtua terlibat di dalam kehidupan anak, dan keterlibatan inilah yang menentukan terbentuknya kesejahteraan psikologis sang anak. Anak dengan kesejahteraan psikologis sendiri dapat dilihat dari tingginya harga diri anak, memiliki evaluasi diri yang positif, dan mampu menjalin interaksi sosial yang baik dengan teman sebaya atau di masyarakat (Cripps \& Zyromski, 2009).

Sebaliknya, beberapa penelitian membuktikan bahwa relasi orangtua-anak yang kurang harmonis dan tidak optimal menimbulkan resiko permasalahan psikologis, terutama ketika anak memasuki masa perkembangan dimana mereka sudah hendak mandiri dari orangtuanya. 
Orang tua yang kaku, kurang memberikan kesempatan pada anak untuk mengambil keputusan, serta sangat mengontrol kehidupan anaknya hanya akan mengakibatkan sang anak menjadi pribadi yang tertutup kepada orang tua dan justru memilih teman sebaya untuk bercerita tentang masalah ataupun cita-cita masa depannya (Fuligni \& Eccles, 1993). Selain itu, relasi antara orang tua dan anak yang sudah penuh dengan konflik juga dapat berpengaruh terhadap harga diri, prestasi akademik, dan tingkat depresi anak. Krishnan (2004) menjelaskan bahwa anak yang sering memiliki konflik dengan orang tua dan dengan permasalahan yang cukup berat cenderung memiliki harga diri dan prestasi akademik yang rendah serta berpotensi lebih besar untuk mengalami depresi dibandingkan dengan anak yang jarang memiliki konflik dengan orang tuanya.

Relasi antara orang tua dan anak dalam ilmu psikologi juga dapat dilihat dari pola pengasuhan orang tua. Orang tua yang mengasuh dengan penuh kasih sayang, hangat, dan memberikan dukungan pada anaknya akan berpengaruh terhadap kesejahteraan psikologis anak yang terlihat dari kebahagiaan dan kepuasan anak hingga dewasa. Namun sebaliknya, orang tua yang sangat mengontrol anak dengan kaku cenderung menjadikan sang anak kurang bahagia, bahkan hingga dewasa (Stafford, Kuha, Galeb, Mishrad \& Richards, 2016). Tidak hanya kualitas relasi antara ibu dan anak, hubungan yang akrab dengan ayah juga ditemukan meningkatkan kebahagiaan, kepuasan, dan mengurangi rasa tertekan atau stress hingga anak menjadi dewasa (Amato, 1994).

Penelitian-penelitian tentang relasi orangtua-anak terdahulu yang menggunakan teori Barat mengungkap relasi orangtua-anak dengan berbagai hal. Antara lain yaitu dengan mengungkapnya melalui dua dimensi bentuk relasi orangtua-anak: dimensi pengasuhan dan dimensi controling (Baumrind, dalam Stafforda, dkk., 2016). Ada pula yang mengungkapnya dengan menggunakan ketegasan orangtua (parental strictness), kesempatan anak untuk mengambil keputusan (decision-making opportunity), dan pantauan orang tua (perceived parental monitoring) (Fuligni \& Eccles, 1993). Ketegasan orang tua yang dimaksud pada konteks tersebut bukanlah menampilkan aspek positif dari kontrol orang tua (monitoring dan pengawasan), namun lebih kepada dominansi otoriter orang tua terhadap sang anak (Fuligni \& Eccles, 1993). Selain itu ada juga yang mengonsep relasi orangtua-anak dari pola asuh orangtua, kontrol psikologis, kehangatan orang tua, dan keterlibatan orang tua dengan anak (Bireda, 2013).

Di dalam Islam, relasi orangtua-anak dilihat secara menyeluruh dan didasarkan pada pemenuhan hak dan kewajiban orangtua dan anak yang berlandaskan pada Al-Quran dan As-Sunnah. Hal ini disebabkan karena relasi orangtua-anak bersifat resiprokal dan tidak dapat dipisahkan (Saeidi, Ajilian, Farhangi, Khodaei, 2014). Mengasuh anak menurut Islam merupakan amanah, dan orang tua akan mempertanggungjawabkan 
amanahnya tersebut di hadapan Allah SWT kelak. Di sisi lain, anak juga memiliki kewajiban untuk berbuat baik, sopan, patuh, dan menghormati orangtua. Karena dalam relasi orangtua-anak, baik orang tua maupun anak memiliki hak dan kewajiban masing-masing yang harus dipenuhi supaya terjadi hubungan yang serasi, harmonis, dan sesuai dengan Al-Quran dan As-Sunnah.

Terkait dengan penjelasan di atas, belum ada penelitian terdahulu yang menyusun skala atau alat ukur untuk mengukur relasi orangtua-anak berdasarkan perspektif Islam. Relasi orangtua-anak hanya dilihat berdasarkan review literatur sehingga lebih sering menggunakan teori Barat walaupun subjek penelitiannya adalah muslim. Hal ini dirasa kurang cocok karena bagaimana orang tua berhubungan dengan anak dan mengasuh anak sangat banyak dipengaruhi oleh nilai-nilai agama dan budaya.

Oleh karena itu, pada penelitian ini akan dilakukan dua studi. Studi pertama ialah melakukan penyusunan, uji reliabilitas dan validitas skala relasi orangtua-anak dengan didasarkan pada penerapan hak dan kewajiban yang berlandaskan nilai-nilai Islam. Adapun studi kedua ialah melakukan uji korelasi antara variabel relasi orangtua-anak dengan kesejahteraan psikologis.

Hasil penelitian sebelumnya banyak menemukan bahwa sering terjadi konflik atau ketidakcocokan antara anak dan orang tua ketika sang anak memasuki masa pencarian jati diri. Anak sering merasa bahwa orang tua tidak paham dengan yang sedang dialami olehnya, sedangkan orang tua sendiri merasa bahwa anak sudah tidak mau menaatinya lagi. Hal ini membuat anak sering terjebak dalam pergaulan yang melanggar norma sosial dan agama.

Dalam Islam, relasi antara orangtua dan anak diatur dengan sempurna. Relasi orangtua-anak dilihat dari bagaimana orang tua dan anak memenuhi hak dan kewajiban masing-masing secara seimbang. Penerapan hak dan kewajiban ini akan membuat relasi orangtua dan anak menjadi harmonis. Islam mengatur bahwa seorang anak berhak memperoleh orang tua yang terbaik. Hal ini penting karena orang tua yang baik akan berelasi dengan anaknya secara baik pula sehingga akan menjadikan anak bahagia dan memiliki kesejahteraan psikologis. Banyak penelitian yang membuktikan bahwa gaya relasi yang tepat akan memberikan dampak positif bagi perkembangan anak, begitu juga sebaliknya. Relasi yang penuh dengan kasih sayang juga sangat penting bagi perkembangan anak. Anak yang berada pada masa pencarian jati diri kadang mengalami kesulitan sehingga mudah terpengaruh oleh pengaruh buruk dari lingkungan.

Rasulullah SAW mengajarkan kepada umat muslim bagaimana menjalin relasi dengan anak, sebagaimana dalam beberapa Hadits Rasulullah SAW antara lain "Apakah terdapat anak-anak di sana?" Tidak lama kemudian, datanglah seorang anak kecil menghampiri Rasulullah. Rasul pun memeluk dan menciumnya sambil berdo'a, "Ya Allah, sayangilah dia dan sayangi 
pula orang yang menyayanginya." (HR. Bukhari). Pada kisah yang lain, suatu hari seorang kepala suku mendatangi Rasulullah dan melihat beliau sedang mencium cucunya. Kepala suku kemudian mengatakan kepada Rasulullah SAW, "Saya mempunyai sepuluh anak, seorang di antara mereka tidak pernah saya cium." Kemudian Rasulullah SAW menjawab, "Kalau Allah tidak memberikanmu perasaan kasih sayang, apa yang dapat diperbuat-Nya untuk kamu? Barangsiapa yang tidak mempunyai kasih sayang pada orang lain, dia tidak akan mendapatkan kasih sayang dari Allah SWT." (HR. Bukhari).

Selain kewajiban orangtua untuk menyayangi dan memenuhi hak anak, anak juga memiliki kewajiban untuk berbakti kepada orang tua. Penelitian yang dilakukan oleh Dinasyari (2013) terhadap anak muslim di Jawa menemukan bahwa makna berbakti kepada orang tua bagi anak adalah bersikap patuh, menghormati, meringankan beban orangtua, bersikap baik, mengabdikan diri, membahagiakan orangtua, dan merupakan perwujudan kewajiban anak terhadap orang tua. Bentuk-bentuk berbakti pada orangtua bagi anak muslim Jawa adalah memenuhi kewajiban anak terhadap orangtua, memiliki karakter diri yang baik, meringankan beban orangtua, dan melaksanakan ajaran agama. Hal ini tampak dari lebih mengutamakan dan mementingkan orang tua dari pada orang lain, mengutamakan kepentingan orang tua di atas kepentingan pribadi, memberikan pelayanan kepada orang tua yang sudah lansia, dan mendoakan ketika orang tua sudah meninggal.

Semua bentuk relasi antara orangtua dan anak ini berpengaruh terhadap kesejahteraan psikologis sang anak. Karabanovaa dan Poskrebysheva (2013) mengungkapkan bahwa relasi antara orang tua dan anak yang positif dapat dilihat dari hubungan emosi yang hangat, minat yang sama, dan kerjasama yang terjalin dengan baik antara keduanya. Relasi yang positif ini ditemukan dapat meningkatkan kepuasan hidup pada anak. Anak yang merasa bahwa orang tuanya memiliki minat yang sama dengannya memberikan sang anak kesempatan untuk mewujudkan hobinya dan juga menjadikannya lebih senang untuk menghabiskan waktu luang bersama dengan orang tua. Adapun relasi emosional yang hangat dengan orang tua, khususnya dengan ibu membuat anak lebih terbuka untuk berbagi rahasia dan sesuatu yang penting kepada orang tuanya. Anak yang merasa puas terhadap relasinya dengan orang tua dapat menjadikannya pribadi yang lebih mandiri. 


\section{METODE PENELITIAN}

\section{Pendekatan Penelitian}

Pendekatan yang digunakan dalam penelitian ini adalah pendekatan kuantitatif, yaitu dua studi berupa studi pengembangan skala relasi orangtua-anak menurut perspektif Islam dan studi korelasi antara variabel relasi orangtua-anak menurut perspektif Islam dengan kesejahteraan psikologis pada anak.

\section{Responden Penelitian}

Responden penelitian ini adalah anak berusia 15-20 tahun yang sedang menempuh pendidikan di beberapa SMA dan duduk di semester satu dalam salah satu perguruan tinggi di Pekanbaru. Teknik pengambilan sampel penelitian ialah dengan cluster random sampling dan jumlah responden direncanakan sebanyak 500 orang atau menyesuaikan dengan jumlah populasi penelitian.

\section{Rancangan Penelitian dan Teknik Analisis Data}

Pada penelitian ini dilakukan dua buah studi, yaitu:

\section{Studi 1: Pengembangan Skala Relasi Orangtua-Anak menurut Perspektif Islam}

Prosedur pengembangan skala relasi orangtua-anak menurut perspektif Islam dikembangkan berdasarkan pendekatan rasional yang dirancang oleh Clark dan Watson (1995) dan telah berhasil diikuti oleh Mahudin, Noor, Dzulkifli, dan Janon (2016). Berikut adalah prosedur yang dimaksud: 


\begin{tabular}{|c|c|c|c|c|c|}
\hline $\begin{array}{l}\text { Konseptualisasi } \\
\text { Skala dan } \\
\text { Penyusunan } \\
\text { Item }\end{array}$ & \multicolumn{2}{|c|}{$\begin{array}{c}\text { Perbaikan Skala } \\
\text { dan Uji } \\
\text { Validitas Skala } \\
\text { I }\end{array}$} & \multicolumn{2}{|c|}{$\begin{array}{c}\text { Uji } \\
\text { Validitas } \\
\text { Skala II }\end{array}$} & $\begin{array}{c}\text { Uji } \\
\text { Validitas } \\
\text { Skala II }\end{array}$ \\
\hline $\begin{array}{l}\text { - Tahap I } \\
\text { - Mendefinisikan } \\
\text { konsep } \\
\text { - Review } \\
\text { literatur (Al- } \\
\text { Quran, Hadits, } \\
\text { pendapat ahli, } \\
\text { dan hasil } \\
\text { penelitian } \\
\text { sebelumnya. } \\
\text { - Penyusunan } \\
\text { item skala }\end{array}$ & $\begin{array}{l}\text { - Tahap II } \\
\text { - Uji } \\
\text { validasi } \\
\text { skala } \\
\text { berdasark } \\
\text { an } \\
\text { penilaian } \\
\text { ahli } \\
\text { - Uji } \\
\text { validitas } \\
\text { konstruk } \\
\text { dan isi } \\
\text { - Perbaikan } \\
\text { item skala }\end{array}$ & $\begin{array}{r}\text { - } \mathrm{Ta} \\
\text { - } \mathrm{Ar} \\
\mathrm{Ra} \\
\mathrm{M} \\
\mathrm{de} \\
\mathrm{W} \\
\text { - Pe } \\
\text { ite } \\
\text { un } \\
\text { sel } \\
\text { - Pe } \\
\text { ite } \\
\text { ur } \\
\text { se }\end{array}$ & $\begin{array}{l}\text { ES } \\
\text { n } \\
\text { a } \\
\text { Iap } \\
\text { ya } \\
\text { n } \\
\text { a } \\
\text { hap } \\
\text { lya }\end{array}$ & $\begin{array}{l}\text { - Tal } \\
\text { - Uji } \\
\text { kon } \\
\text { al }\end{array}$ & crement \\
\hline
\end{tabular}

\section{Studi 2: Uji Korelasi antara Variabel Relasi Orangtua-Anak menurut Perspektif Islam dengan Variabel Kesejahteraan Psikologis}

Hasil penelitian terdahulu menemukan bahwa relasi orangtua-anak berkorelasi dengan kesejahteraan psikologis. Pada penelitian ini peneliti akan melakukan uji korelasi regresi linear berganda antara relasi orangtua-anak menurut perspektif Islam dengan kesejahteraan psikologis.

\section{HASIL PENELITIAN}

\section{STUDI 1: Pengembangan Skala Relasi Orangtua-Anak menurut Perspektif Islam}

Pengembangan skala relasi orangtua-anak menurut perspektif Islam dilakukan melalui empat tahap, yaitu:

\section{Tahap 1: Konseptualisasi Skala dan Penyusunan Item}


Pada tahap ini dilakukan konseptualisasi skala relasi orangtuaanak berdasarkan pelaksanaan hak dan kewajiban antara keduanya. Landasan teori yang digunakan bersumber pada Al-Quran, Hadits, pendapat ahli dan hasil penelitian sebelumnya. Adapun aspek dari relasi orangtua-anak disusun dari terpenuhinya hak anak oleh orang tua yaitu hak mendapatkan orang tua yang terbaik, hak untuk hidup ketika dalam kandungan, hak untuk memperoleh pengasuhan yang baik, hak untuk memperoleh perawatan yang layak, hak untuk bersosialisasi, hak untuk mendapatkan pendidikan, dan hak untuk mendapatkan perlakuan yang adil. Selanjutnya juga disusun aspek relasi orangtua-anak dari sisi pelaksanaan kewajiban oleh anak terhadap orang tua atau terpenuhinya hak orangtua atas anaknya, yaitu hak emosional yang berupa hak untuk dihargai, dihormati dan diperlakukan baik oleh anaknya, artinya anak wajib menghargai, menghormati dan memperlakukan orangtua dengan baik; hak untuk mendidik dan dipatuhi oleh anak, artinya anak wajib mematuhi dan mentaati aturan dan didikan orangtuanya; dan hak untuk didoakan oleh anak, artinya anak wajib mendoakan orangtuanya.

\section{Tahap II: Uji Validitas Konstruk dan Isi}

Setelah dilakukan penyusunan item berdasarkan aspek-aspek di atas, langkah selajutnya ialah proses analisis validasi isi berdasarkan pendapat ahli atau orang yang dianggap memahami konsep relasi orangtua- anak berdasarkan perspektif Islam. Berdasarkan pendapat ahli tersebut, maka dilakukan perbaikan terhadap item pada skala dan tersusun 29 item untuk skala relasi orangtua anak (pelaksanaan kewajiban bagi orang tua terhadap anak) dan 15 item untuk skala relasi orangtua-anak (pelaksanaan kewajiban bagi anak terhadap orang tua). Adapun pilihan jawabannya adalah SS (Sangat Sesuai), S (Sesuai), N (Netral), KS (Kurang Sesuai), dan TS (Tidak Sesuai).

\section{Tahap III: Perbaikan Skala dan Uji Validitas dan Reliabilitas Menggunakan Analisis Rasch Model dengan WINSTEPS}

Pada tahap ketiga ini dilakukan uji validitas dan reliabilitas menggunakan Rasch Model dengan WINSTEPS. Jumlah partisipan penelitian adalah 185 orang siswa salah satu MAN di Pekanbaru Riau dan mahasiswa semester satu Fakultas Psikologi UIN Suska 
Riau, dengan rentang usia 13-20 tahun (rerata usia 15,7 tahun, SD 1,51). Analisis validitas konstruk dilakukan penyusunan item berdasarkan aspek relasi orangtua anak berdasarkan perspektif Islam. Selanjutnya dilakukan analisis Rasch Model dengan WINSTEPS. Hasil analisis menemukan reliabilitas person dan item (interaksi antara person dan item secara keseluruhan) tinggi yaitu dengan nilai alpha Cronbach 0,88 . Secara khusus hasil analisis juga menemukan bahwa person reliability dan item reliability pada skala ini juga tinggi yaitu 0.80 dan 0,96 .

Tabel 1

Summary Statistic Relasi Orangtua-Anak

SUMMARY OF $\mathbf{1 8 4}$ MEASURED
(NON-EXTREME)

MAXIMUM EXTREME SCORE: 1 Person

SUMMARY OF 185 MEASURED
(EXTREME AND NON-EXTREME)


Relasi Orangtua-Anak Menurut Perspektif Islam Dan Kaitannya Dengan.....

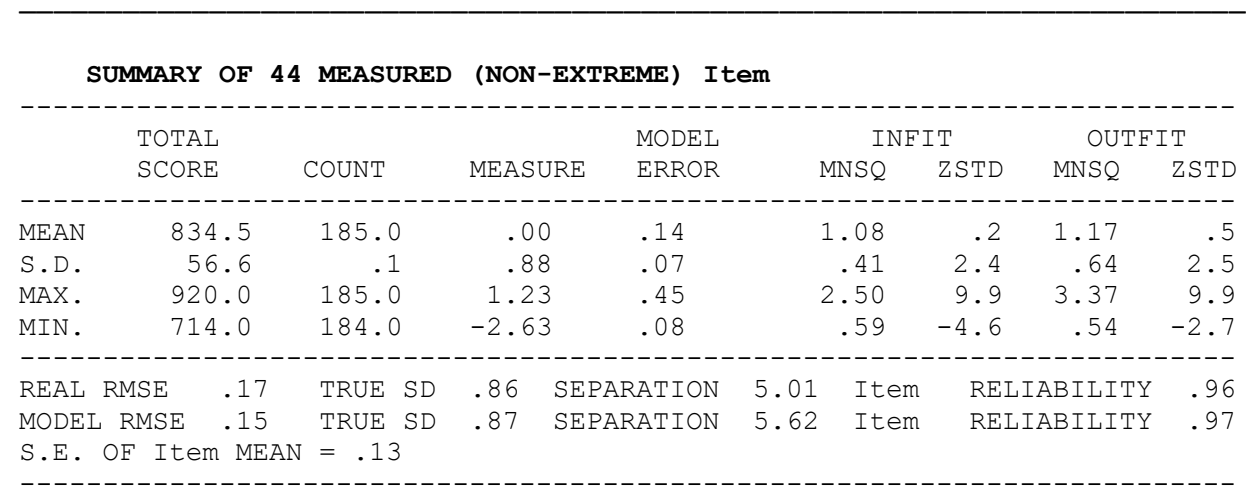

$\mathrm{UMEAN}=.0000$ USCALE $=1.0000$

Item RAW SCORE-TO-MEASURE CORRELATION $=-.92$

8095 DATA POINTS. LOG-LIKELIHOOD CHI-SQUARE: 12471.30 with 7865 d.f. $\mathrm{p}=.0000$

Global Root-Mean-Square Residual (excluding extreme scores): .6804

Skala memiliki kualitas yang baik terbukti dari nilai rata-rata INFIT MNSQ dan OUTFIT MNSQ secara berurutan adalah 1,08 dan 1,17 (nilai idealnya adalah 1,00 , dan semakin mendekati 1,00 maka semakin baik). Nilai rata-rata INFIT ZSTD dan OUTFIT ZSTD adalah 0,41 dan 0,64 dimana nilai idealnya adalah 0,0 (makin mendekatan 0,0 maka kualitasnya makin baik).

\section{Tabel 2}

\section{Item Statistics}

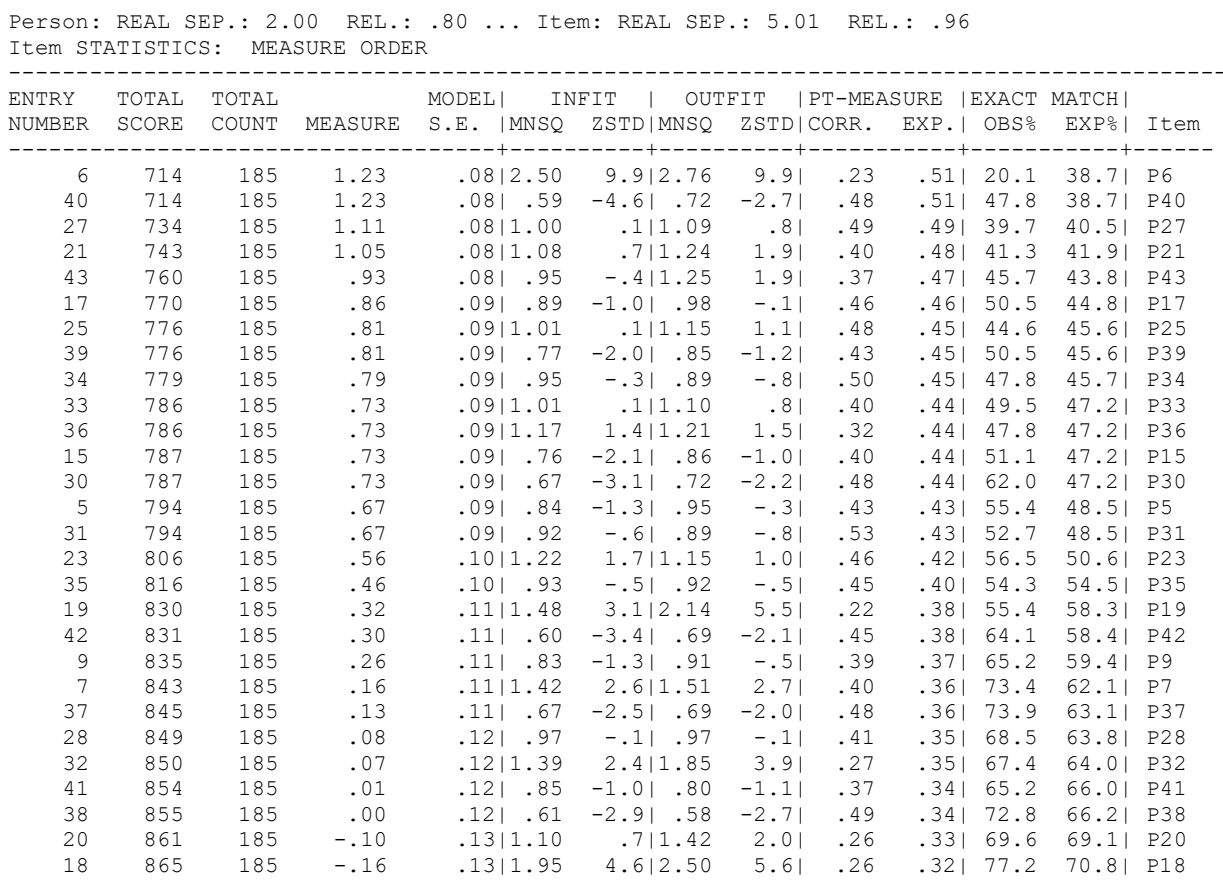




\begin{tabular}{|c|c|c|c|c|c|c|c|c|c|c|c|}
\hline 3 & 869 & 185 & -.23 & $.13 \mid .90$ & $-.6 \mid 1.03$ & .21 & .31 & .311 & 77.7 & 72.81 & P3 \\
\hline 16 & 871 & 185 & -.27 & $.14 \mid 1.63$ & $3.2 \mid 1.72$ & 3.01 & .33 & .301 & 81.0 & 73.41 & P16 \\
\hline 22 & 875 & 185 & -.35 & $.14 \mid 1.37$ & $1.9 \mid 1.26$ & 1.21 & .34 & .291 & 79.9 & 75.41 & P22 \\
\hline 29 & 875 & 185 & -.35 & $.14 \mid 1.14$ & $.81 \quad .77$ & $-1.1 \mid$ & .45 & .291 & 81.0 & 75.41 & P29 \\
\hline 12 & 883 & 185 & -.52 & $.15 \mid .72$ & $-1.6 \mid .54$ & -2.41 & .46 & $.27 \mid$ & 81.0 & 79.11 & P12 \\
\hline 13 & 884 & 185 & -.55 & $.16 \mid .78$ & $-1.2 \mid .61$ & $-1.9 \mid$ & .43 & $.27 \mid$ & 82.6 & 79.61 & P13 \\
\hline 10 & 886 & 185 & -.60 & $.16 \mid .77$ & $-1.2 \mid .55$ & -2.21 & .47 & $.26 \mid$ & 84.8 & 80.81 & $\mathrm{P} 10$ \\
\hline 26 & 887 & 185 & -.62 & $.16 \mid 1.01$ & $.1 \mid 1.07$ & $.4 \mid$ & .28 & .261 & 82.6 & 81.51 & P2 6 \\
\hline 8 & 892 & 185 & -.76 & $.17 \mid 1.00$ & .11 .68 & $-1.4 \mid$ & .40 & $.24 \mid$ & 84.8 & 83.91 & P8 \\
\hline 14 & 897 & 185 & -.93 & $.19 \mid 1.68$ & $2.6 \mid 1.07$ & .41 & .31 & .231 & 89.7 & 86.41 & P14 \\
\hline 11 & 903 & 185 & -1.17 & $.21 \mid .88$ & $-.4 \mid .58$ & $-1.6 \mid$ & .37 & .201 & 89.7 & 89.01 & P11 \\
\hline 24 & 905 & 185 & -1.26 & $.22 \mid 1.05$ & $.3 \mid 1.24$ & .81 & .18 & .191 & 89.7 & 89.91 & P2 4 \\
\hline 44 & 904 & 184 & -1.48 & $.25 \mid 2.20$ & 3.313 .37 & 4.41 & .11 & $.17 \mid$ & 95.1 & 91.91 & P 44 \\
\hline 2 & 911 & 185 & -1.61 & $.27 \mid .80$ & $-.6 \mid \quad .55$ & $-1 \cdot 3 \mid$ & .31 & $.16 \mid$ & 92.4 & 92.91 & P2 \\
\hline 1 & 914 & 185 & -1.85 & $.30 \mid 1.21$ & .71 .86 & -.21 & .23 & $.14 \mid$ & 95.1 & 94.31 & $\mathrm{P} 1$ \\
\hline 4 & 920 & 185 & -2.63 & $.45 \mid 1.36$ & .912 .73 & 2.31 & -.01 & .101 & 97.8 & 97.41 & P 4 \\
\hline MEAN & 834.5 & 185.0 & .00 & $.14 \mid 1.08$ & $.2 \mid 1.17$ & .51 & & I & 67.2 & $64.1 \mid$ & \\
\hline S.D. & 56.6 & .1 & .88 & $.07 \mid .41$ & 2.41 .64 & 2.51 & & 1 & 18.1 & $17.5 \mid$ & \\
\hline
\end{tabular}

Kualitas skala juga dilihat dari nilai separation. Semakin besar nilai separation maka kualitas skala dalam hal keseluruhan responden dan butir semakin bagus, karena mampu mengidentifikasi kelompok responden dan kelompok butir. Pada skala ini ditemukan nilai separation 5,01 (dibulatkan menjadi 5), artinya pada skala ini terdapat tiga kelompok butir soal, yaitu soal yang sangat sulit, sulit, sedang, agak mudah, dan mudah.

Selain itu, data di atas juga menunjukkan bahwa nilai indeks pemisahan orang yang baik (good person separation index) yaitu 2,0 . Hal ini memiliki makna bahwa skala relasi orangtua-anak mampu memisahkan relasi orangtua-anak yang baik dan kurang baik. Analisis Rasch Model juga menemukan 8 item yang kurang fit atau kurang valid yaitu item nomor 4, 6, 14, 16, 18, 19, 32, dan 44. Hasil analisis uji unidimensionalitas menunjukkan bahwa skala relasi orangtua-anak memenuhi persyaratan unidimensionalitas (nilai standardized residual variance $29,4 \%$, lebih besar dari syarat minimal yaitu 20\%), artinya skala relasi orangtua-anak layak dan mengukur apa yang hendak diukur. Ada perbaikan yang sebaiknya dilakukan terhadap peringkat pilihan jawaban yaitu dengan menyederhanakannya menjadi 4 pilihan jawaban karena responden penelitian bingung membedakan antara pilihan jawaban Sesuai (S) dengan Sangat Sesuai (SS). 


\section{Tabel 3 \\ Standardized Residual}

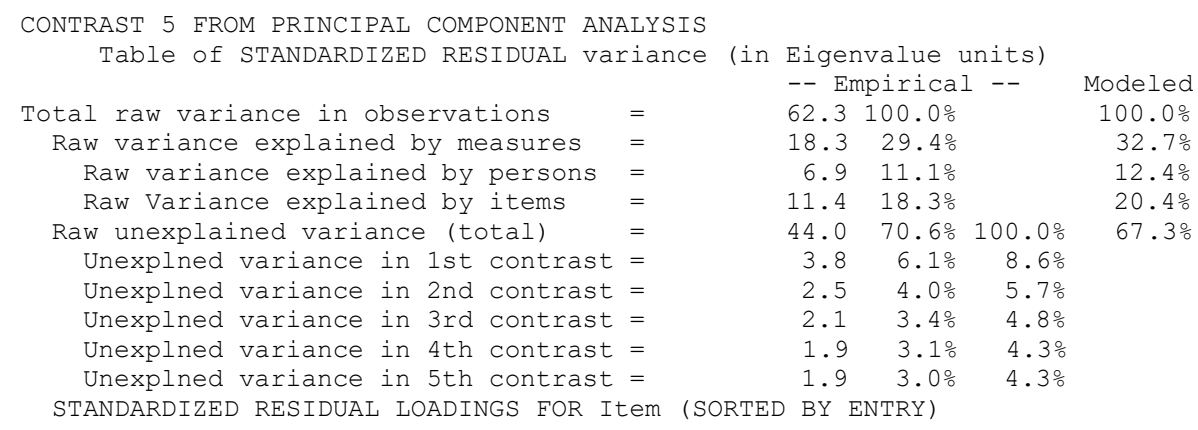

\section{Tabel 4}

\section{Summary Of Category Structure. Model="R"}

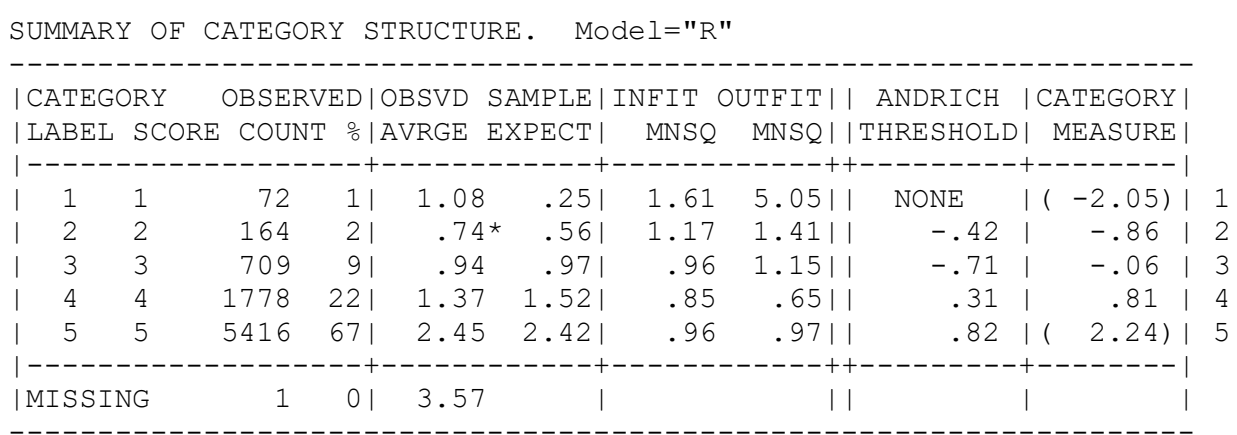

\section{Tahap 4: Uji Validitas Konkuren}

Uji validitas konkuren dilakukan dengan mengkorelasikan skala relasi orangtua-anak menurut perspektif Islam dengan kesejahteraan psikologis. Hal ini dilakukan karena berdasarkan hasil penelitian sebelumnya, ditemukan bahwa relasi orangtua-anak berkorelasi dengan kesejahteraan psikologis pada anak. Uji korelasi dilakukan pada 149 responden. Hasil analisis korelasi Product Moment Pearson menemukan bahwa terdapat korelasi yang sangat signifikan antara relasi orangtua-anak menurut perspektif Islam dengan kesejahteraan psikologis pada anak $(\mathrm{p}<0,001, \mathrm{r} 0,516)$. Hal ini memiliki arti bahwa skala relasi orangtua-anak menurut perspektif Islam memiliki validitas konkuren. 


\section{Tabel 5}

Uji Validitas Konkuren

\begin{tabular}{lcccl}
\hline \multicolumn{1}{c}{ Variabel } & $\begin{array}{c}\text { Jumlah } \\
\text { Responden }\end{array}$ & R & $\mathbf{p}$ & Keterangan \\
\hline Relasi Orangtua & 149 & 0,516 & 0,001 & Sangat \\
Anak*Kesejahteraan & & & & Signifikan \\
Psikologis & & & & \\
\hline
\end{tabular}

\section{STUDI 2: Uji Korelasi antara Variabel Relasi Orangtua-Anak menurut Perspektif Islam dengan Variabel Kesejahteraan Psikologis}

Pada studi kedua ini peneliti melakukan uji korelasi regresi linear berganda untuk melihat korelasi antara variabel relasi orangtua-anak menurut perspektif Islam (penerapan hak anak dan kewajiban orangtua dan hak orangtua dan kewajiban anak) dengan kesejahteraan psikologis pada 305 responden yang terdiri dari siswa MAN dan mahasiswa semester 1 .

Hasilnya ditemukan bahwa terdapat korelasi positif yang sangat signifikan yaitu $\mathrm{p}<0,001$ dan $\mathrm{R}$ Square 0,101 . Hal ini memiliki makna bahwa relasi orangtua-anak yang dilihat dari penerapan hak dan kewajiban oleh orangtua dan anak menurut perspektif Islam memiliki korelasi yang positif dengan kesejahteraan psikologis pada anak. Sumbangan efektif relasi orangtua-anak terhadap kesejahteraan psikologis anak adalah 10,1\%.

\section{Tabel 6}

Hasil Uji Korelasi Regresi Linear Berganda

\begin{tabular}{lccccl}
\hline \multicolumn{1}{c}{ Variabel } & R & $\mathbf{r}^{2}$ & F & P & Keterangan \\
\hline $\begin{array}{l}\text { Hak Orangtua dan } \\
\text { Kewajiban Anak }\end{array}$ & & & & & $\begin{array}{l}\text { Sangat } \\
\text { \& Hak Anak dan Kewajiban } \\
\begin{array}{l}\text { Orangtua*Kesejateraan } \\
\text { Psikologis }\end{array}\end{array}$ \\
\hline
\end{tabular}

Sedangkan untuk analisis parsial antara persepsi terhadap penerapan hak anak dan kewajiban orangtua terhadap kesejahteraan psikologis anak dengan persepsi terhadap penerapan hak orangtua dan kewajiban anak terhadap kesejahteraan psikologis anak ditemukan hasil bahwa masing-masing variabel tersebut memiliki korelasi positif yang sangat signifikan (p 0,005 < 0,01; B0,564 dan p 0,001<0,01; B1,088, secara berurutan). 


\section{Tabel 7}

\section{Hasil Uji Korelasi Parsial}

\begin{tabular}{lllll}
\hline Variabel & B & Beta & p & Keterangan \\
\hline $\begin{array}{l}\text { Hak Orangtua dan Kewajiban Anak } \\
\text { *Kesejahteraan Psikologis }\end{array}$ & 0,564 & 0,164 & 0,005 & Sangat \\
$\begin{array}{l}\text { Hak Anak dan Kewajiban } \\
\text { Orangtua*Kesejateraan Psikologis }\end{array}$ & 1,088 & 0,225 & 0,001 & \\
\hline
\end{tabular}

\section{Pembahasan}

Tujuan penelitian ini yaitu penyusunan skala relasi orangtuaanak menurut perspektif Islam dan uji korelasi dengan kesejahteraan psikologis pada anak tercapai dengan baik. Hasil penelitian menemukan 36 item yang valid dan reliabel untuk mengukur relasi orangtua-anak menurut perspektif Islam, dimana item ini dibagi menjadi 23 item untuk mengukur penerapan hak anak dan kewajiban orangtua menurut persepsi anak, serta 13 item untuk mengukur penerapan hak orangtua dan kewajiban anak menurut persepsi anak.

Adapun aspek yang diwakilkan kepada 23 item skala relasi orangtua-anak yang digunakan untuk mengukur terhadap persepsi anak terhadap haknya dan kewajiban yang harus ditunaikan oleh orangtua adalah hak anak untuk memperoleh orangtua yang terbaik, hak untuk hidup ketika dalam kandungan, hak untuk memperoleh pengasuhan yang baik, hak untuk memperoleh perawatan yang layak, hak untuk bersosialisasi, hak untuk mendapatkan pendidikan, dan hak untuk mendapatkan perlakuan yang adil.

Sedangkan 13 item yang digunakan untuk mengukur hak orangtua dan kewajiban anak menurut persepsi anak, mewakili aspek hak emosional yaitu hak untuk dihargai, dihormati dan diperlakukan baik oleh anaknya, artinya anak wajib menghargai, menghormati dan memperlakukan orangtua dengan baik; hak untuk mendidik dan dipatuhi oleh anak, artinya anak wajib mematuhi dan mentaati aturan dan didikan orangtuanya; hak untuk didoakan oleh anak atau kewajiban anak untuk mendoakan orangtuanya. Selanjutnya alat ukur ini akan diberi nama "Skala Relasi Orangtua-Anak UIN Suska Riau".

Penelitian juga menemukan bahwa terdapat korelasi positif yang sangat signifikan antara relasi orangtua-anak menurut perspektif Islam dengan kesejahteraan psikologis pada anak. Hal ini memberikan gambaran bahwa penerapan hak dan kewajiban bagi orangtua dan anak memiliki korelasi dengan pencapaian kesejahteraan psikologis pada anak atau akan membuat anak menjadi 
tenang dan bahagia. Hasil penelitian ini mendukung hasil penelitian sebelumnya yang menemukan bahwa salah satu komponen yang dapat membentuk kesejahteraan psikologis pada orangtua dan anak adalah relasi yang baik antara orangtua dan anak (Noor, Gandhi, Ishak \& Wok, 2012).

\section{KESIMPULAN DAN SARAN}

\section{Kesimpulan}

Berdasarkan penjelasan tentang hasil penelitian di atas, dapat disimpulkan bahwa penelitian ini telah berhasil menemukan suatu alat ukur yang dapat digunakan untuk mengukur relasi orangtua-anak berdasarkan perspektif Islam, yang diberi nama "Skala Relasi OrangtuaAnak UIN Suska Riau". Hasil uji validitas konkuren menemukan bahwa skala ini terbukti berkorelasi secara positif dengan kesejahteraan psikologis.

\section{Saran}

Berdasarkan hasil temuan di atas, disarankan kepada peneliti selanjutnya yang ingin mengukur variabel relasi orangtua-anak untuk menggunakan skala ini, khususnya jika responden adalah muslim. 


\section{DAFTAR PUSTAKA}

Ali, F., Belembaogo, A., Hegazi, S., \& Khaled, N. (2005). Children in Islam. Their care, upbringing and protection. Al-Azhar University in cooperation with the United Nations Children's Fund (UNICEF).

Ahmed, M. E. (2011). The Rights of Parents. India: Al-Ather Islamic Centre Purani Haveli.

Amato, P. R. (1994). Father-child relations, mother-child relations, and offspring psychological well-being in early adulthood. Journal of Marriage and Family, 56 (4), 1031-1042.

Arfat, S. (2013). Islamic perspective of the children's rights: an overview. Asian Journal of Social Sciences \& Humanities, 2 (1), 299307.

Armsden, G. C. \& Greenberg, M. T. (1987). The inventory of parent and peer attachment: individual differences and their relationship to psychological well-being in adolescence. Journal of Youth and Adolescence, 16 (5), 427-454.

Bireda, A. D. (2013). Parent-adolescent relationship and Adolescents' adjustment problems: adolescents' voices. Dissertation, online publication. South Africa: University Of South Africa.

Cader, S. K. A. (2003). Family Life in Islam/ Women in Islam. South Africa: Islamic women studies scholar.

Chaturvedula, S. \& Joseph, C. (2007). Dimensions of psychological well-being and personality in military aircrew: A preliminary study. Ind J Aerospace Med 51(2), 17-27.

Clark, L. A., \& Watson, D. (1995). Constructing validity: Basic issues in objective scale development. Psychological Assessment, 7(3), 309319. 
Cripps, K. \& Zyromski, B. (2009). Adolescents' Psychological WellBeing and Perceived Parental Involvement:Implications for Parental Involvement in Middle Schools. Research in Midle Level Education Online, 33 (4), 1-13.

Dinasyari, Y. N. (2013). Makna berbakti pada orangtua dalam perspektif anak Mbnlljjuslim. Naskah Publikasi Skripsi. Fakultas Psikologi dan Fakultas Agama Islam, Universitas Muhammadiyah Surakarta.

Fuligni, A. J. \& Eccles, J.S. (1993). Perceived parent-child relationships and early adolescents' orientation toward peers. Developmental Psychology, 29 (4),622-632.

Gholozani, Y. M. (2014). Rights of Parents in Parent-Child Relationship from Islamic Perspective. Technical Journal of Engineering and Applied Sciences, 4(3), 111-114.

Karabanovaa, O. A. \& Poskrebysheva, N. N. (2013). Adolescent autonomy in parent-child relations. Procedia-Social and Behavioral Sciences, 621-628.

Krishnan, U. D. (2004). Parent-adolescent conflict and adolescent functioning in a collectivist, ethnically heterogenous culture: Malaysia. Dissertation, online publication.Department of Philosophy, The Ohio State University, Ohio.

Mahudin, N, D, M. Noor, N. M., Dzulkifli, M. A., \& Janon, N. S. (2016). Religiosity among Muslims: A Scale Development and Validation Study. Makara Hubs-Asia, 20 (2), 109-120.

Noor, N. M., Gandhi, A. D., Ishak, I., \& Wok, S. (2014). Development of Indicators for Family Well-Being in Malaysia. Social Indicators Research, 115 (1), 279-318.

Ryff, C.D. (1989). Happiness Is Everything or Is It? Explorations on the Meaning of Psychological Well-Being. Journal of Personality and Social Pyschology. 57 (6) 1069-1081. 
Ryff, C.D. \& Keyes, C.L.M. (1995). The Structure of Psychological Well-Being Revisited. Journal of Personality and Social Psychology. 69 (4), 719-727.

Stafford, M., Kuha, D. L., Galeb, C. R., Mishrad, G., \& Richards, M. (2016). Parent-child relationships and offspring's positive mental wellbeing from adolescence to early older age. The Journal of Positive Psychology, 11, (3), 326-337. 